\title{
AGROTEKNIKA
}

ISSN: 2685-3450 (Online)

www.agroteknika.id

ISSN: 2685-3450 (Print)

\section{Studi Daya Hantar Listrik Terhadap Mutu Fisiologis Benih Kedelai (Glycine max (L.) Merr.) dengan Perlakuan Invigorasi Matriconditioning dan Osmoconditioning}

\section{The Study of Electric Conductivity With Physiological Quality of Soybean (Glycine max (L.) Merr.) Seeds by Matriconditioning and Osmoconditioning Invigoration Treatment}

\author{
Puguh Bintang Pamungkas*, Muhammad Kusberyunadi
}

Program Sarjana Agroteknologi, Fakultas Pertanian, Universitas PGRI Yogyakarta, Indonesia

*Penulis Korespondensi

Email: puguhbintang4478@gmail.com

\begin{abstract}
Abstrak. Deteriorasi menghambat usaha dalam pemenuhan kebutuhan kedelai nasional. Imbas proses tersebut menyebabkan kualitas benih kedelai berkurang. Invigorasi dilakukan untuk meningkatkan kualitas benih. Tujuan dari penelitian ini agar dapat mengetahui korelasi antara daya hantar listrik dengan variabel fisiologis benih kedelai. Percobaan berlangsung di laboratorium Agroteknologi Universitas PGRI Yogyakarta dan laboratorium Kimia Universitas Mercu Buana Yogyakarta. Metode penelitian menggunakan Rancangan Acak Lengkap 5 faktor dengan 3 ulangan. Pengamatan terdiri dari kadar air, daya berkecambah, indeks vigor dan daya hantar listrik. Berdasar percobaan yang dilakukan, terdapat perbedaan yang nyata antar perlakuan pada variabel daya berkecambah dan indeks vigor, sedangkan pada variabel kadar air tidak menunjukkan perbedaan yang nyata. Regresi yang dilakukan memperlihatkan adanya korelasi positif antar variabel daya hantar listrik-kadar air, sedang korelasi negatif terdapat antara variabel daya hantar listrik-daya berkecambah dan daya hantar listrik-indeks vigor. Kualitas benih dapat dilihat melalui kebocoran membran sel, kebocoran elektrolit tinggi pada benih (P4) dianggap kualitasnya rendah, sedangkan kebocoran elektrolit rendah pada benih (P0) dianggap kualitasnya tinggi.
\end{abstract}

Kata kunci: daya hantar listrik, elektrolit, invigorasi, kedelai, vigor

Abstract. The deterioration prevents efforts to meet the needs of national soybean. The impact of this process makes the quality of soybean seeds is reduced. Efforts which is conducted to improve the quality of seeds are invigoration. The research was aimed to find out the correlation between electrical conductivity with physiological variables of soybean seeds. The research took place in the Agrotechnology laboratory PGRI University of Yogyakarta and the Chemistry laboratory Mercu Buana University of Yogyakarta. The research method using a completely randomized design of 5 factors and 3 replications. The variable i.e water content, seed germination, index vigor, and electric conductivity. Based on research results, there was no significant difference between treatments in water content, while on the germination and vigor index are significantly different between treatments. The regression results show, there is a positive correlation between electrical conductivity-water content, while the negative correlation between electrical conductivity-seed germination and electrical conductivity-vigor index. Seed quality can be seen through cell membrane leakage, high electrolyte leakage is considered low quality, while low electrolyte leakage is considered high quality.

Diterima : 12 Februari 2020

Disetujui : :28 Juni 2020

Diterbitkan : 29 Juni 2020

Doi: https://doi.org/10.32530/agroteknika.v3i1.56

Artikel ini adalah artikel open access di bawah lisensi CC BY-SA 4.0 
Keyword: electric conductivity, electrolyte, invigoration, soybean, vigor

\section{Pendahuluan}

Glycine max (L.) Merr. atau tanaman kedelai mengandung sekitar 35-38\% protein, lebih banyak dibandingkan beras dan jagung. Semakin meningkatnya jumlah penduduk, konsumsi akan kedelai juga meningkat, namun kenyataannya produksi kedelai menurun. Berdasarkan data Kementan (2019), produksi kedelai turun dari 955.000 ton ke 539.000 ton, diikuti juga penurunan luas panen dari 616.000 ton ke 356.000 ton pada tahun 2014-2017.

Beberapa usaha dilakukan guna meningkatkan produksi kedelai, salah satunya adalah penggunaan benih bermutu. Tetapi, dilapangan banyak dijumpai benih kedelai yang bermutu rendah karena tempat penyimpanan yang tidak optimal, bahkan disimpan lebih dari 3 bulan. Dengan demikian, benih tidak berkecambah dengan baik ketika ditanam.

Selain dipengaruhi masa simpan, mutu benih juga dipengaruhi proses deteriorasi atau kemunduran benih. Proses deteriorasi tersebut berlangsung begitu cepat dan mempengaruhi mutu fisiologis dan biokima benih selama penyimpanan. Menurut Sadjad (1980), benih bermutu merupakan benih yang tetap mampu menjaga sifatnya (fisik, fisiologis dan biokomia) meskipun sudah melalui proses produksi sampai penyimpanan.

Perkecambahan kedelai dipengaruhi oleh suhu pada ruang simpan (Kartono, 2004), hal ini sesuai pernyataan Copeland and Mc Donald (2001), bahwa saat fase penyimpanan aspek internal (genetik, indeks vigor serta daya perkecambahan) dan aspek eksternal (kemasan serta suhu dan kelembaban ruang simpan) mempengaruhi viabilitas benih.

Banyak cara diusahakan agar mendorong peningkatan nilai viabilitas benih, diantaranya osmoconditioing, dan matriconitioning. Osmoconditioning, metode yang dilakukan dengan mempergunakan larutan osmotic seperti $\mathrm{KH}_{2} \mathrm{PO}_{4}, \mathrm{KON}_{3}, \mathrm{PEG}, \mathrm{NaCl}$. Matriconditioning, metode yang dilakukan dengan mempergunakan media lembap seperti vermikulit, arang sekam, pasir, abu gosok dan serbuk gergaji. Percobaan ini dilakukan dengan tujuan dapat mengetahui korelasi antara daya hantar listrik dengan variabel fisiologi benih kedelai.

\section{Bahan dan Metode}

Penelitian dilaksanakan Januari sampai dengan April 2020 di laboratorium Agroteknologi Universitas PGRI Yogyakarta dan laboratorium Kimia Universitas Mercu Buana Yogyakarta. Alat yang digunakan plastik, kertas minyak, kertas buram, timbangan analitik, oven, conductivity meter, grinder, labu kjedhal, erlenmeyer, pipet tetes, alat destruksi-destilasi-titrasi, label, alat tulis, kamera. Bahan yang digunakan benih kedelai varietas Anjasmara dengan daya berkecambah $<80 \%$, aquades, katalisator, $\mathrm{H}_{2} \mathrm{SO}_{4}$ pekat, $\mathrm{H}_{3} \mathrm{BO}_{3} 4 \%$, campuran $\mathrm{NaThio}+\mathrm{NaOH}, \mathrm{CaCO}_{3}$, dan $\mathrm{HCl} 0.02 \mathrm{~N}$, media matriconditioningvermikulit; serbuk gergaji, media osmoconditioning larutan $\mathrm{KNO}_{3} 2 \%$; $\mathrm{NaCl} 2 \%$. 
Percobaan yang dilakukan mempergunakan metode Rancangan Acak Lengkap 5 faktor dan 3 ulangan, dimana faktor terdiri dari P0 = tanpa invigorasi; P1 = invigorasi matriconditioning vermikulit; P2 = invigorasi matriconditioning serbuk gergaji; P3 = invigorasi osmoconditioning $\mathrm{KNO}_{3} 2 \%$; serta $\mathrm{P} 4$ = invigorasi osmoconditioning NACl $2 \%$.

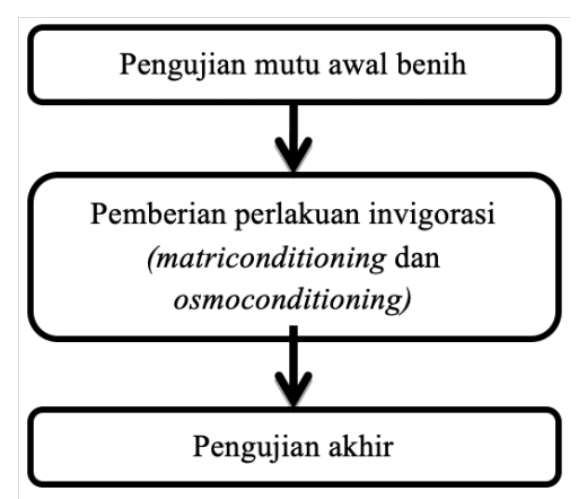

Gambar 1. Proses pelaksanaan pengujian

Invigorasi diberikan sesuai dengan media perlakuan yang sudah ditetapkan. Menurut ElAbady (2014), pada perlakuan matriconditioning terdapat perbandingan 9:6:7, yakni 9 g benih, 6 $\mathrm{ml}$ air dan 7 g media, kemudian komposisi tersebut dicampurkan dan didiamkan 12 jam, setelah itu dikering anginkan. Sedangkan perlakuan osmoconditioning terdapat perbandingan 50:35, yakni $50 \mathrm{~g}$ benih dan $35 \mathrm{ml}$ media, benih tersebut direndam pada media $12 \mathrm{jam}$, setelah itu dikering anginkan.

Tabel 1. Hasil analisa mutu benih awal kedelai varietas Anjasmoro

\begin{tabular}{llc}
\hline No & \multicolumn{1}{c}{ Peubah } & Hasil analisa \\
\hline 1 & Kadar air (\%) & 12,18 \\
2 & Daya berkecambah (\%) & 70 \\
3 & Indeks vigor & 7,19 \\
4 & Kemurnian benih (\%) & 98,22 \\
5 & Kotoran benih (\%) & 1,52 \\
\hline
\end{tabular}

Pengujian terhadap variabel dilakukan sebelum dan sesudah percobaan. Variabel yang diuji saat sebelum percobaan terdiri dari indeks vigor, daya berkecambah dan kadar ari, sedangkan untuk pengujian sesudah percobaan sama dengan pengujian sebelumnya hanya ditambah dengan daya hantar listrik. Analisis data dilakukan dengan ANOVA (Analysis of Variance) 5\%, jika diketahui terdapat pengaruh yang nyata maka selanjutnya pengujian lanjut dilakukan menggunakan DMRT (Duncan's New Multiple Range Test) 5\%

\section{Hasil dan Pembahasan}

\section{Mutu Benih Awal}

Mutu benih awal sebelum penyimpanan sangat menentukan daya simpan benih, dimana hal tersebut dapat menentukan perlakuan dan kesimpulan yang tepat. Pada Tabel 1, disajikan data mutu awal benih kedelai sebelum percobaan. 


\section{Kadar Air}

Analisis ragam kadar air benih kedelai sesudah pemberian perlakuan disajikan pada Tabel 2 .

Tabel 2. Purata kadar air benih kedelai varietas Anjasmoro setelah diberi perlakuan invigorasi matriconditioning dan osmoconditioning

\begin{tabular}{lc}
\hline \multicolumn{1}{c}{ Perlakuan Invigorasi } & Purata \\
\hline & \\
P0 (Kontrol) --- Kadar air (\%) --- & $12,36 \mathrm{a}$ \\
P1 (Matriconditioning Vermikulit) & $12,62 \mathrm{a}$ \\
P2 (Matriconditioning Serbuk gergaji) & $12,23 \mathrm{a}$ \\
P3 (Osmoconditioning $\mathrm{KNO}_{3}$ 2\%) & $13,36 \mathrm{a}$ \\
P4 (Osmoconditioning $\mathrm{NaCl} 2 \%)$ & $12,78 \mathrm{a}$ \\
\hline
\end{tabular}

Keterangan: Angka pada purata yang diikuti huruf yang sama menunjukkan tidak ada beda nyata menurut DMRT 5\%.

Menurut percobaan yang dilakukan, perlakuan P2 menunjukkan persentase kadar air yang lebih unggul dari perlakuan lainnya. Persentase kadar air perlakuan P2 sebesar 12,23 \%, sedangkan perlakuan lain berkisar dari 23,36-13,36 \%. Perlakuan P2 memperlhatkan bahwa media yang digunakan mampu menahan laju penambahan kadar air benih, sejalan dengan Ilyas et al., (2000) yang menyatakan adanya perbedaan sifat permukaan antara serbuk gergaji dengan media lain, sehingga mempengaruhi kemampuan memegang airnya.

Tabel 3. Purata daya berkecambah benih kedelai varietas Anjasmoro setelah diberi perlakuan invigorasi matriconditioning dan osmoconditioning

\begin{tabular}{lc}
\hline \multicolumn{1}{c}{ Perlakuan Invigorasi } & Purata \\
\hline \multicolumn{1}{c}{$\quad---$ Daya berkecambah (\%) } & --- \\
P0 (Kontrol) & $68,00 \mathrm{ab}$ \\
P1 (Matriconditioning Vermikulit) & $62,00 \mathrm{~b}$ \\
P2 (Matriconditioning Serbuk gergaji) & $68,67 \mathrm{a}$ \\
P3 (Osmoconditioning KNO $\mathrm{K}_{3} \%$ ) & $56,67 \mathrm{~b}$ \\
P4 (Osmoconditioning NaCl 2\%) & $60,67 \mathrm{~b}$ \\
\hline
\end{tabular}

Keterangan: Angka pada purata yang diikuti huruf yang sama menunjukkan tidak ada beda nyata menurut DMRT $5 \%$.

Menurut Widajati et al., (2013), kualitas benih sangat berpengaruh pada persentase kadar air yang dikandungnya, jika kandungan kadar air tinggi maka kemunduran benih juga akan meningkat, serta sebaliknya. Begum et al., (2013) juga menyatakan saat proses deteriorasi berlangsung, kadar karbohidrat pada benih mengalami penyusutan, namun kadar air dan daya hantar listrik akan bertambah justru mengalami peningkatan.

\section{Daya Berkecambah}

Analisis ragam daya berkecambah benih kedelai sesudah pemberian perlakuan disajikan pada Tabel 3.

Dari percobaan yang dilakukan, pemberian invigorasi matriconditioning serbuk gergaji (P2) menunjukkan nilai daya berkecambah yang lebih unggul dari perlakuan lainnya. Ilyas et al., (2000) menyatakan bahwa hal tersebut dikarenakan medium serbuk gergaji berbeda atas medium lainnya dalam hal karakter permukaannya, sehingga mempengaruhi kemampuan memegang airnya. 
Serbuk gergaji mempunyai kemampuan dalam memegang air lebih unggul dari media lainnya, selain itu ada efek vermikulit yang mampu mengakibatkan kerusakan pada kulit benih saat pencampuran dan inkubasi dilakukan dengan media, oleh sebab itu untuk meningkatkan daya berkecambah benih kedelai penggunaan media matriconditioning serbuk gergaji dinilai lebih optimal dibanding media lainnya.

Hasil dari variabel daya berkecambah yang diperoleh dalam percobaan yang telah dilakukan termasuk rendah, yaitu antara 56,57-68,67 \%. Hal tersebut mengindikasikan proses deteriorasi yang berlangsung mempengaruhi dan menurunkan mutu fisiologis benih kedelai.

Deteriorasi yang terjadi di fase penyimpanan benih kedelai, proses ini dapat berlangsung sangat cepat jika penyimpanan benih kedelai dilakukan pada keadaan yang tidak optimum. Proses deteriorasi tersebut mampu menurunkan nilai indeks vigor dan daya berkecambah benih secara signifikan, imbasnya adalah persentase perkecambahan yang rendah dan benih akan rentan pada cekaman maupun penyakit (Ilyas, 2006).

Steinbauer-Sadjad menerangkan mengenai teori viabilitas benih, dimana di dalamnya terdapat indeks vigor dan daya berkecambah, dimana teori tersebut berkembang menjadi konsepsi Steinbauer-Sadjad yang pemikirannya dikembangkan menjadi kuantifikasi metabolisme benih (Sadjad, 1989).

Lakitan (2000), menerangkan mengenai hubungan fase serapan air dengan metabolisme benih dalam proses deteriorasi pada benih. Pada fase I reaksi biokimia yang terjadi pada benih diawali dengan hidrasi substansi terlebih dahulu, walaupun penyerapan air yang terjadi tidak terkait pada proses metabolisme benih. Pada fase II penyerapan air akan berhenti, namun nyatanya proses metabolisme tetap berlangsung dengan aktif untuk permulaan perkecambahan, selanjutnya pada fase III penyerapan air berhubungan dengan kemunculan radikula. Berdasarkan, penjelasan yang di paparkan di atas, benih yang mengalami deteriorasi diduga pada fase I terjadi kebocoran, sehingga berpengaruh pada metabolisme di fase II dan imbasnya fase III terdapat kecambah abnormal.

Deteriorasi yang berlangsung cepat pada benih jagung dapat dipicu oleh fluktuasi suhu dan kelembapan ruang simpan (Arief et al., 2004), selain itu faktor genetik masing-masing varietas juga dapat menjadi faktor pendorong cepatnya proses deteriorasi berlangsung. Pernyataan tersebut didukung oleh Copeland and Mc Donald (2001), menyatakan aspek internal benih (genetk, perkecambahan, indeks vigor dan kadar air benih awal) mampu mempengaruhi viabilitas benih, hal tersebut juga sesuai dengan pendapat Kartono (2004) bahwa banyak yang mempengaruhi daya berkecambah benih: (a) mutu benih; (b) kadar air; (c) suhu dan kelembaban ruang simpan; (d) organisme penganggu di ruang simpan; dan (e) lama periode simpan. 


\section{Indeksi Vigor}

Analisis ragam indeks vigor benih kedelai sesudah pemberian perlakuan disajikan pada Tabel 4.

Tabel 4. Purata indeks vigor benih kedelai varietas Anjasmoro setelah diberi perlakuan invigorasi matriconditioning dan osmoconditioning

\begin{tabular}{lc}
\hline \multicolumn{1}{c}{ Perlakuan Invigorasi } & Purata \\
\hline & \\
P0 (Kontrol) --- Indeks vigor --- & $6,92 \mathrm{ab}$ \\
P1 (Matriconditioning Vermikulit) & $6,25 \mathrm{~b}$ \\
P2 (Matriconditioning Serbuk gergaji) & $7,04 \mathrm{a}$ \\
P3 (Osmoconditioning $\mathrm{KNO}_{3} 2 \%$ ) & $5,57 \mathrm{~b}$ \\
P4 (Osmoconditioning NaCl 2\%) & $6,00 \mathrm{~b}$ \\
\hline
\end{tabular}

Keterangan: Angka pada purata yang diikuti huruf yang sama menunjukkan tidak ada beda nyata menurut DMRT $5 \%$.

Menurut percobaan yang dilakukan, perlakuan P2 menunjukkan nilai indeks vigor tertinggi jika dibandingkan dengan perlakuan yang lain. Namun, jika indeks vigor yang diperoleh dibandingkan dengan indeks vigor awal benih masih tergolong rendah, ini memperlihatkan bahwa indeks vigor menurun yang diakibatkan oleh proses deteriorasi yang terjadi.

Copeland and Mc Donald (2001) menyatakan variabel indeks vigor merupakan nilai yang memperlihatkan berapa banyak perkecambah normal yang tumbuh dari hari pertama, yaitu hari ke-4 uji perkecambahan benih. Nilai dari indeks vigor yang tinggi memberikan arti bahwa daya berkecambah benih lebih cepat, sehingga benih termasuk bervigor kuat, begitu juga sebaliknya jika nilai indeks vigor rendah memberikan arti bahwa daya berkecambah benih lambat, sehingga benih termasuk bervigor rendah.

Suatu benih yang dapat tumbh cepat memperlihatkan bahwa benih tersebut dapat tumbuh dalam keadaan yang tidak optimum (Sadjad, 1994). Nilai indeks vigor yang menurun diikuti pula dengan nilai daya berkcambah yang menurun selama penyimpanan, dapat disimpulkan bahwa di akhir penyimpanan nilai indeks vigor benih akan semakin menurun.

\section{Daya Hantar Listrik}

Analisis ragam daya hantar listrik benih kedelai sesudah pemberian perlakuan disajikan pada Tabel 5 .

Tabel 5. Purata daya hantar listrik benih kedelai varietas Anjasmoro setelah diberi perlakuan invigorasi matriconditioning dan osmoconditioning

\begin{tabular}{lc}
\hline \multicolumn{1}{c}{ Perlakuan Invigorasi } & Purata \\
\hline --- Daya hantar listrik $\left(\mu S \mathrm{~cm}^{-1} \mathrm{~g}^{-1}\right)---$ \\
P0 (Kontrol) & $24,06 \mathrm{~b}$ \\
P1 (Matriconditioning Vermikulit) & $28,21 \mathrm{~b}$ \\
P2 (Matriconditioning Serbuk gergaji) & $34,54 \mathrm{~b}$ \\
P3 (Osmoconditioning KNO $2 \%)$ & $34,41 \mathrm{~b}$ \\
P4 (Osmoconditioning NaCl 2\%) & $42,60 \mathrm{a}$ \\
\hline
\end{tabular}

Keterangan: Angka pada purata yang diikuti huruf yang sama menunjukkan tidak ada beda nyata menurut DMRT $5 \%$. 
Skor daya hantar listrik benih kedelai menurut hasil penelitian yang sudah dilakukan bersifat fluktuatif, dimana skornya ada pada kisaran 24,06 sampai $42,60 \mu \mathrm{S} \mathrm{cm}^{-1} \mathrm{~g}^{-1}$. Hasil terendah dari daya hantar listrik ditunjukkan oleh perlakuan P0 yakni sebesar $24,06 \mu \mathrm{S} \mathrm{cm}^{-1} \mathrm{~g}^{-1}$, sedangkan untuk skor tertinggi ditunjukkan oleh perlakuan P4 yakni sebesar $42,60 \mu \mathrm{S} \mathrm{cm}^{-1} \mathrm{~g}^{-1}$. Hal ini seperti pernyataan Begum et al., (2013) dalam periode simpan benih terjadi perubahan biokimia dalam benih kedelai, seperti kandungan kadar air dan daya hantar listrik mengalami peningkatan, kandungan karbohidrat dan protein mengalami penurunan.

Variabel percobaan daya hantar listrik merupakan percobaan mutu benih dapat memberikan informasi mengenai level kebocoran pada membran sel benih. Apabila level kebocoran elektrolit tinggi, dapat diartikan bahwa benih tersebut bervigor rendah, dan sebakiknya tingkat kebocoran elektrolit rendah, dapat diartikan bahwa benih tersebut bervigor tinggi (ISTA, 2005). Benih yang sedang menjalani proses imbibisi, apabila struktur benih tersebut rusak maka dapat melepaskan elektrolit dari dalam benih keluar benih, elektrolit tersebut dapat dideteksi oleh conductivity meter, hal tersebut dikarenakan elektrolit dalam media imbibisi membawa muatan listrik, sehingga jumlah muatan listrik dalam aquades/air rendaman benih akan menentukan besar kecilnya skor daya hantar listrik benih.

Skor daya hantar listrik pada penelitian terdahulu cenderung meningkat seiring dengan periode penyimpanan dan proses deteriorasi yang berlangsung (Beedi et al., 2018; Nabila et al., 2016; Naguib et al., 2011; Noviana et al., 2017; Pamungkas et al., 2018). Daya hantar listrik yang tinggi menunjukkan bahwa membrane sel benih mengalami kerusakan, sehingga banyak elektrolit yang keluar benih, dimana zat yang dimaksud adalah asam amino, gula, enzim dan ion organik $\left(\mathrm{K}^{+}, \mathrm{Ca}^{2+}, \mathrm{Mg}^{2+}, \mathrm{Na}^{2+}\right.$ dan $\left.\mathrm{Mn}^{2+}\right)$ (Beedy et al., 2018) dan (Dias et al., 2004).

\section{Hubungan Daya Hantar Listrik Dengan Karakter Fisiologis}

Analisa regresi dan korelasi yang dilakukan untuk memahami kualitas benih kedelai, sebagai imbas dari perlakuan invigorasi matriconditioning dan osmoconditioning terhadap daya hantar listrik.

Daya hantar listrik (sumbu x) dan kadar air, daya berkecambah serta indeks vigor (sumbu y), hubungan yang dibentuk kedua sumbu dinyatakan dalam persamaan garis regresi, dimana besar kecilnya koefisien korelasi memperlihatkan peubah y dipengaruhi oleh peubah x sebesar nikai koefisien tersebut.

Kadar air dipengaruhi oleh daya hantar listrik ditunjukkan pada Gambar 2, dimana pola yang dibentuk antara keduanya (DHL-KA) membentuk hubungan positif yang dibuktikan dengan adanya kemiringan (slope) positif, sehingga dapat diartikan jika daya hantar listrik yang terukur tinggi maka akan diikuti peningkatan kadar air benih. Dalam regresi ini, nilai koefisien korelasi 
(r) sebesar 0,346 dimana dapat diartikan bahwa 34,6\% kadar air benih hanya dipengaruhi oleh daya hantar listrik.

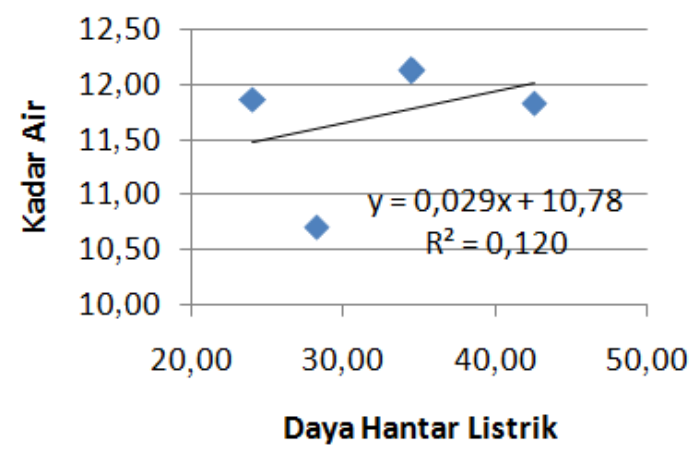

Gambar 2. Regresi antara daya hantar listrik - kadar air

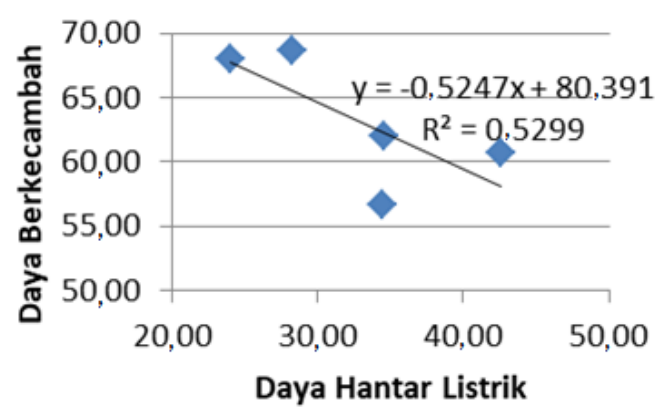

Gambar 3. Regresi antara daya hantar listrik - daya berkecambah

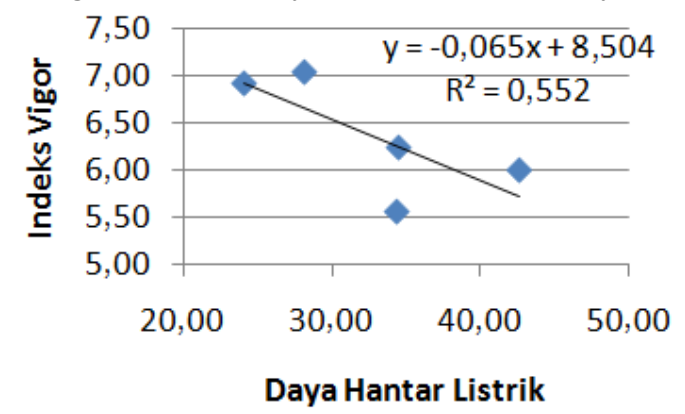

Gambar 4. Regresi antara daya hantar listrik - indeks vigor

Daya perkecambahan dan indeks vigor dipengaruhi oleh daya hantar listrik secara berurutan ditunjukkan oleh Gambar 3 dan 4, dmana pola yang dibentuk antara keduanya (DHL-DB) dan (DHL-IV) membentuk hubungan negative yang dibuktikan dengan adanya kemiringan (slope) negative, sehingga dapat diartikan jika daya hantar listrik yang terukur tinggi maka akan diikuti oleh penurunan daya perkecambahan dan indeks vigor benih. Dalam regresi ini, besaran nilai koefisien korelasi (r) masing-masing adalah -0.727 dan -0.743 dimana dapat diartikan bahwa 72,7 $\%$ daya berkecambah dan $74,3 \%$ indeks vigor benih hanya dipengaruhi oleh daya hantar listrik.

Penelitian terdahulu oleh Balachander et al., (2018); Pamungkas et al., (2018) dan Mahawar et al., (2018) memperlihatkan efek yang hampir sama pada percobaan kali ini, dimana penambahan nilai daya hantar listrik akan diikuti penambhan kadar air benih, namun variable daya berkecambah dan indeks vigor justru mengalami penurunan, keadaan tersebut disebabkan karena adanya elektrolit yang keluar dari benih saat imbibisi berlangsung. 


\section{Kesimpulan}

Salah satu variabel penentu kualitas benih adalah daya hantar listik (DHL), hal ini dikarenakan daya hantar listrik dapat menunjukkan kebocoran membran sel benih. Pada percobaan yang sudah dilakukan, diperoleh hasil nilai daya hantar listik (DHL) ada pada kisaran 24,06 sampai $42,60 \mu \mathrm{S} \mathrm{cm}^{-1} \mathrm{~g}^{-1}$. Skor daya hantar listik (DHL) terendah ada pada perlakuan P0 yakni 24,06 $\mu \mathrm{S}$ $\mathrm{cm}^{-1} \mathrm{~g}^{-1}$, situasi tersebut dapat diartikan perlakuan P0 merupakan benih bervigor tinggi karena tingkat kebocoran elektrolit yang rendah. Sebaliknya, skor daya hantar listik (DHL) tertinggi pada perlakuan P4 yakni sebesar $42,60 \mu \mathrm{S} \mathrm{cm}^{-1} \mathrm{~g}^{-1}$, situasi tersebut dapat diartikan perlakuan P4 merupakan benih bervigor rendah karena tingkat kebocoran elektrolit yang tinggi.

Dilihat dari aspek korelasi, variabel daya hantar listrik memiliki hubungan negative dengan variabel daya berkecambah dan indeks vigor, dapat diartikan peningkatan daya hantar listrik maka akan menyebabkan penurunan daya berkecambah dan indeks vigor. Sebaliknya, variabel daya hantar listrik memiliki hubungan positif dengan variable kadar air, dapat diartikan peningkatan daya hantar listrik maka akan menyebabkan peningkatan juga pada variabel kadar air benih.

\section{Ucapan Terimakasih}

Ucapan terimakasih disampaikan atas terlaksananya penelitian yang telah dilakukan, dimana penelitian ini didanai melalui Hibah Penelitian Dosen Pemula dari Lembaga Penelitian dan Pengabdian kepada Masyarakat Universitas PGRI Yogyakarta.

\section{Daftar Pustaka}

Arief, R., Syam'un, S., \& Saenong, S. (2004). Evaluasi mutu fisik dan fisiologis benih jagung CV. Lamuru dari ukuran biji dan umur simpan yang berbeda. Jurnal Sains \& Teknologi, 4(2), 54-64.

Balachander, B. S., Harshika Netha, N., \& Dalvi, D.G.(2018). Effect of genotypes and containers on physiological and biochemical changes during storage of soybean seed (Glycine max L. Merrill). Int.J.Curr.Microbiol.App.Sci, 6(Special Issue), 1836-1851.

Beedi, S, Macha, S. I., Gowda, B., Savitha, A. S., \& Kurnallikar, V. (2018). Effect of seed priming on germination percentage, shoot length, root length, seedling vigour index, moisture content and electrical conductivity in storage of kabuli chickpeacv., MNK-1 (Cicer arietinum L.). Journal of Pharmacognosy and Phytochemistry, 7(1), 2005-2010.

Begum, A. J., Jerlin, R., \& Jayanthi, M. (2013). Seed quality changes during storage of oil seedsa review. International Journal of Scientific Research. 2(10),1-2.

Copeland, L. O., \& Mc Donald, M. B. (2001). Principles ofSeed Science and Technology 4th edition. New York, USA: Kluwer Academic Publishers.

Dias, D. C. F. S., Freitas, R. A., Dias, L. A. S., \& Olivera, M. G. A. (2004). Storage Potential Of Cotton Seeds Predicted By Vigour Tests And Biochemical Assays. 27th ISTA Congress, Budapest, Hungary, 2004, 70.

El-Abady, M. I. (2014). Viability of Stored Maize Seed Exposed to Different Periods of High Temperature During the Artificial Drying. Research Journal of Seed Science. 1(7), 75-86.

Ilyas, S., Hasan, A., Siregar, U. J., \& Sudarsono. (2000). Matriconditioning Improve yard-long Bean Seed Quality. Third International Crop Science Congress, Hamburg, 17-22 August 2000 . 
Ilyas, S. (2006). Seed treatment using matriconditioning to improve vegetable seed quality. Bul. Agron., 34(2), 124-132.

ISTA. (International Seed Testing Association). (2005). Annexe to Chapter 15: Seed VigourTesting. International Rules for Seed Testing ed. 5.

Kartono. (2004). Teknik penyimpanan benih kedelai varietas wilis pada kadar air dan suhu penyimpanan berbeda. Bul. Tek. Pertanian, 9(2),79-82.

Kementan, (Kementerian Pertanian Republik Indonesia). (2019). Data Lima Tahun Terakhir. Retrieved from http://www.pertanian.go.id/home/?show=page\&act=view\&id=61.

Lakitan, B. (2000). Dasar-Dasar Fisiologi Tumbuhan. Jakarta, Indonesia: PT. Radja Grafindo Persada.

Mahawar, M. K., Samuel, D. V. K., Sinha, J. P., \& Jalgaonkar, K. (2018). Moisture-Dependent Physical and Physiological Properties of Accelerated Aged Pea (Pisum sativum L.) seeds. Current Science, 114 (4), 909-915.

Nabila, S. M., Amin, A. K. M. R., Islam, Md. O., Haque, Md. N., \& Achakzai, A. K. K. (2016). Effect of storage containers on the quality of wheat seed at ambient storage condition. AmEurasian J. Agric. Environ. Sci. 16, 402-409.

Naguib, N.A., Mohamed, E.A.I.,\& El-Aidy, N.A.(2011). Effect of storage period and packaging material on wheat (Triticum aestivum L.) seed viability and quality. Egypt. J. Agric. Res. 89(4), 1481-1497.

Noviana, I., Alit Diratmaja, IGP., Qadir, A., \& Suwarno, F.C.(2017). Pendugaan deteriorasi benih kedelai (Glycine max L. Merr) selama penyimpanan. Jurnal Pertanian Agros, 19 (1), 1-12.

Pamungkas, P.B., Supriyono., \&Purwanto, E.(2018). The relations of electric conductivity with physiological characteristic of soybean(Glycine Max (L) Merr) seeds by matriconditioning invigoration treatment when stored. Acta Universitatis Et Silviculturae Mendelianae Brunensis, 66(4): 883-888. https://doi.org/10.11118/actaun201866040883

Sadjad, S. (1980). Panduan Mutu Benih Tanaman Kehutanan di Indonesia. Bogor, Indonesia: Institut Petanian Bogor (IPB).

Sadjad, S. (1989). Konsepsi Steinbauer-Sadjad Sebagai Landasan Matematika Benih di Indonesia. Orasi Ilmiah. Bogor, Indonesia: IPB.

Sadjad, S. (1994). Kuantifikasi Metabolisme Benih. Jakarta, Indonesia: PT Gramedia Widiasarana.

Widajati, E., E. Murniati, E.R. Palupi, T. Kartika, M. R. Suhartanto, A. Qadir. (2013). Dasar Ilmu dan Teknologi Benih. Bogor, Indonesia: PT. Penerbit IPB Press. 